Pobrane z czasopisma Annales H - Oeconomia http://oeconomia.annales.umcs.pl Data: 26/04/2023 10:49:32

DOI:10.17951/h.2019.53.4.7-20

\begin{tabular}{lcc}
\hline \multicolumn{1}{c}{ A N N A L E S } \\
UNIVERSITATIS MARIAE CURIE-SKŁODOWSKA \\
LUBLIN - POLONIA \\
VOL. LIII, 4 & SECTIOH H \\
\hline
\end{tabular}

\author{
JUSTYNA BOGOŁĘBSKA \\ justyna.bogolebska@uni.lodz.pl \\ University of Lodz. Faculty of Management \\ 22/26 Matejki St, 90-237 Lodz, Poland \\ ORCID ID: https://orcid.org/0000-0002-3730-1849
}

\title{
Properties for Sale in Attractive Holiday Locations: The Most Important Elements
}

Keywords: real estate; rental of real estate; investment decisions

JEL: R3; G17

How to quote this paper: Bogołębska, J. (2019). Properties for Sale in Attractive Holiday Locations: The Most Important Elements. Annales Universitatis Mariae Curie-Skłodowska, sectio H-Oeconomia, Vol. 53, No. 4.

\begin{abstract}
Based on surveys, the characteristic areas of the holiday real estate market were indicated. A model was presented in which a forecast for the development of the residential market was assumed. The implementation of the objective set in the article contributed to the explanation of the complex phenomenon of holiday properties for sale.
\end{abstract}

\section{Introduction}

The real estate market is still not fully researched. In the source literature, it is difficult to find a comprehensive study on the real estate market. The shape of the real estate market in a given country in a period of time is the result of many evolutionary changes (Belniak, 2001, p. 203). Creating the foundations of the market economy for the real estate market in countries undergoing systemic transformation took place under difficult economic and socio-political conditions. Because of these changes, the 
real estate market is complicated, and this often prevents the application of certain model simplifications to obtain a clear picture of reality. The market nature of each economy is emphasised by the role of real estate as a component of national wealth. Given my own research among developers preparing holiday properties for sale, it seems that the role of this segment of the real estate market will be increasingly significant in the future. The role will also be particularly important to individual investors seeking alternative sources of diversification of the asset portfolio. The aim of the article is to examine the statistical significance for holiday properties in the northern and southern macroregion. ${ }^{1}$ In connection with the above, qualitative (surveys intended for developers of the construction industry) and quantitative (a simplified linear model built with the least squares method) research was used. In addition, the characteristics (survey questions 1-5) determining the functioning of the holiday real estate market were examined regarding whether they were statistically significant when divided into the northern and southern macroregions.

\section{Real estate as an important element of the economy}

Investments in holiday properties can be treated as an instrument of the financial market because they are bought to diversify the portfolio. The real estate sector is an important area of the economy which, to a significant extent, shapes the basic economic phenomena, such as investments, savings, the economic situation, employment, tangible assets, the efficiency of the banking sector and the attitude and satisfaction of the society (Dziworska \& Trojanowski, 2007, p. 10). There are three types of real estate under Polish law: land, buildings and parts of buildings, also called "premises". There are two conventional classifications of property in the source literature. The first is the classification by sector - depending on purpose, there is commercial real estate and residential real estate. ${ }^{2}$ The second classification of real estate is by location and geographical region. The above classification results from economic factors shaping a given area and the consequent prices of given real estate (Hoesli, Lizieri, \& MacGregor, 1997, pp. 1475-1494). Originally, the real estate was used by its owners, but as the market developed, the situation changed and currently a landlord renting a property for tourism purposes can also use it, thus, giving the

\footnotetext{
1 The definition of macroregions is given in the database of the Local Data Bank and adopts the division of Poland according to specific voivodships. For the purpose of researching into and defining common features of holiday investments for sale, it was assumed that the northern macroregion includes the following voivodships: Pomeranian (pomorskie), Warmian-Masurian (warmińsko-mazurskie), West Pomeranian (zachodniopomorskie), whereas the southern macroregion includes: Lower Silesian (dolnoślaskie), Lesser Poland (małopolskie), Opole (opolskie), Subcarpathian (podkarpackie), Silesian (śląskie) and Holy Cross (świętokrzyskie).

2 Commercial real estate: retail and office real estate, real estate used to provide a range of services, as well as industrial real estate.
} 
investment function to holiday properties. Real estate becomes an object of market turnover to achieve individual housing goals or to run a business. In addition, real estate can be traded for investment purposes to achieve a revenue stream in the form of rents, or a capital gain in the form of a positive difference between the selling price and the purchase price (Kucharska-Stasiak, 2016, p. 43).

The analysis of the situation on the property market is an important reference point for the stability of the financial system and results from financing this type of investment with a loan. Too many profound changes in the area of credit supply and demand may upset the stability of the financial system. According to the established methodology of the National Bank of Poland (NBP), the real estate sector primarily consists of the segment of residential property and the segment of commercial property. The property market is linked with other sectors of the economy; thus, the connections and the impact on the financial situation of the country remain strong.

Moreover, holiday properties for sale are a new investment category, and the knowledge of its most important features and determining factors can contribute to rapid development in the near future. The construction and sale of holiday apartments to individual investors in appropriate locations, particularly those which will generate an income from vacation rental to the property owner, is an option of diversifying the development activity. Due to its geographical location, Poland is characterised by a changing climate throughout the year. The weather is an unpredictable factor in the long term; thus, the tourist season is identified with the holiday period resulting from the calendar.

When going on a summer domestic vacation, the Poles most often opt for the Baltic Sea coast and the mountains (54.7\% of indications for the Baltic Sea and 31.8\% of indications for the mountains) (SW RESEARCH, 2018). ${ }^{3}$ Domestic holidays are chosen most often, among others, because of the short distance, lower costs and habits. The Poles opt to organise holidays by themselves more often, e.g. through portals, indicating that they do not want to be dependent on a group, or because the price of a vacation package is too high. Therefore, holiday properties for rent and for personal use, which are purchased by individual investors, should be increasingly popular because this type of offer is intended for tourists who want to organise their vacations alone. An additional element that influences the increase in interest in this type of real estate is the improvement of the financial situation of Polish people. Therefore, the purchase of holiday properties seems to be a good investment and a surplus cash investment. The economic situation is conducive to investing in this type of fixed assets because Poland is a developed country, but property prices differ significantly from the prices in other European countries. In the case of such investments, the rate

3 The aim of the study (SW RESEARCH, 2018) was to create a report describing the leisure habits of Poles - what places they prefer, what kind of recreation they choose and how they organise their holidays. The Internet-panel survey was carried out on 12-20 July 2016 by the SW RESEARCH agency using online interviews (CAWI) on the SW Panel. As a part of the survey, 1,021 questionnaires were completed by a representative group of Poles of 18 or over 18 years of age. 
of return earned by individual investors is an important argument to decide whether to buy a given property. As research particularly showed, the rate of return on this type of investment was determined by real estate development companies at $6 \%$ to $8 \%$ per annum. The holiday property for sale is not defined under Polish law, and the adopted terminology is borrowed from foreign markets. Under the Polish tax law, especially in the area of the amortisation of fixed assets, it is assumed that such properties are residential premises.

\section{Selection of the sample and the methodology for performed tests}

The study was intended for the representatives of real estate development companies who had been operating in the construction industry for at least six years and had offered at least three residential investments for sale, which were later intended for tourists to rent. In connection with the above, the two most attractive tourist areas in Poland were chosen (detailed characteristics in section 3). The choice remains justified because the demand for holiday properties in these areas is high. Subsequently, selected respondents were then able to observe the mechanisms determining the development of the market for holiday property for sale and, on the basis of it, to determine many important and characteristic features of this sector.

The survey was conducted with the CATI method and 80 respondents participated: 40 from the northern macroregion and 40 from the southern macroregion. Non-probability sampling of respondents was adopted in the research sample. The study was intended for 100 development companies. Thus, 80 respondents answered the questions in the survey. It consisted of 19 questions -7 open-ended and 12 close-ended. Completed qualitative research in the form of a survey does not always answer the most important issues related to a given topic because this kind of research contains an element of subjectivity - in short, the opinion of respondents participating in a given study. This is not a factual error; however, it was decided at that point to supplement the qualitative tests with the statistical tests.

Due to the lack of a definition of what "holiday property for rent" is, in the second part of the study, it was decided to create a model to forecast the number of completed residential premises. The assumption was made that the explanatory variables were the average remuneration and the number of marriages. The selection of the three variables for the model resulted from the following assumptions:

1. As the average remuneration increases, the willingness to invest and buy residential premises also increases - during the first stage to satisfy the housing needs, during the second stage to diversify the portfolio of investments (the transition from the first stage to the second stage comes with ageing).

2. The number of completed residential premises reflects the supply and the developer's capacity in the construction industry. 
3. The number of marriages is the result of the assumption that the marriage aims to create an independent and separate household and buying a flat is a strategy to achieve the established goal.

The collected data came from the archives of the Central Statistical Office for the years 1995-2017. According to the source literature, the first step of model construction was to calculate the means for explained and explanatory variables, the standard deviation and the coefficient of variation (Witkowska, 2012, p. 36). The calculation of variables was intended for choosing the appropriate parameters to build the econometric model. During the next stage, the correlation coefficients between the explained variable and the explanatory variables were calculated, and also between the explanatory variables. Multiple regression analysis was used to estimate the coefficients. The variance inflation factor (VIF) coefficient was calculated to show the lack of collinearity and the Durbin-Watson test was performed to assess the occurrence of autocorrelation among the rest.

\section{Qualitative research among investors offering holiday properties for sale}

The research was carried out in the northern and southern parts of Poland. Therefore, it was assumed that northern Poland included the voivodships which have access to the Baltic Sea ${ }^{4}$ and southern Poland included the voivodships which are characterised, above all, by the mountainous area. ${ }^{5}$ In connection with this, the following terminology was adopted: "the northern macroregion" and "the southern macroregion".

In conclusion, it was assumed that respondents from the northern macroregion were developers who built holiday rentals located within a maximum distance of 10 $\mathrm{km}$ from the sea, while respondents from the southern macroregion were developers who built holiday properties for sale located within a maximum distance of $10 \mathrm{~km}$ from the mountain ranges. The respondents in the study were development companies which had been operating in the holiday real estate for sale industry for more than six years. Additionally, the respondents were divided in accordance with the adopted assumptions pertaining to the locations. In the research sample, non-probability sampling was adopted. The study was intended for 100 development companies. Consequently, 80 respondents answered the questions in the survey. It consisted of 19 questions - 7open-ended and 12 close-ended. Due to the issues raised in the article, some questions were omitted in the presented results. The questions included in the survey were divided into two groups: the first group of questions characterised the

\footnotetext{
4 The voivodships in northern Poland: West Pomeranian, Pomeranian and Warmian-Masurian (3.7 $\mathrm{km}$ of coastline in the port of Elbląg).

5 In Europe, a mountain range is any mountain which is $500 \mathrm{~m}$ above sea level; thus, in the area of southern Poland, the following voivodships included: Lower Silesian, Lesser Poland, Opole, Subcarpathian, Silesian and Holy Cross.
} 
activity performed by development companies and the second group of questions concerned the factors related to the conducted activity. In the following article, the results of the survey obtained from the respondents' answers to the questions by the first group were presented.

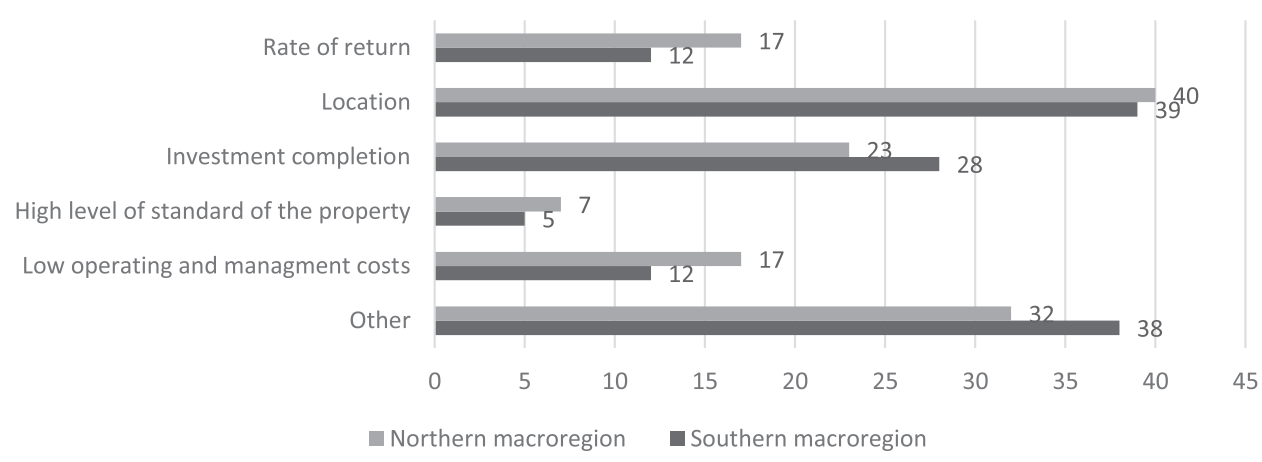

Figure 1. Factors determining the investors' choices of a given holiday property

Source: Author's own study.

The survey was a hybrid of a multiple-choice question and an open-ended question to be completed with other factors (price, living area, surroundings, access to infrastructure) determining the investors' choices, if the respondent considered it necessary. The most important factor determining the selection of a given summer investment by individual investors turned out to be the location ( 79 indications for this answer option in both analysed geographical areas). This factor seems particularly important because a well-chosen location determines the investor's future earnings. The indications for answer option 4 - the level of the rate of return earned from a given investment by individual investors - is interesting because there were 29 such indications. In the context of the source literature, which indicates that the rate of return is one of the important factors in undertaking investments, 29 indications seem to rank the rate of return as a significantly less important factor in the area of holiday investments. Therefore, it can be assumed that making a holiday property investment for the purpose of renting it, the investor is driven by other more important factors (investment finishing standard, location, price, property surroundings, surrounding infrastructure) rather than the desire to earn money. The second most important factor in choosing the investment, according to the respondents, is the standard of finishing the investment. Based on the preliminary research, holiday investments for rent are finished in accordance with the investor's order. ${ }^{6}$

6 The examination of the offers of development companies presenting holiday properties for sale with the aim of renting them. This analysis was carried out based on 250 selling offers. 
The investor is presented with options of finishing and the relevant cost calculation. Possible standards of finishing also include the option of the development standard of the investment, which, when chosen, entails the investor's own interior finish. The respondents selected the price (59 indications) as an additional factor influencing the attractiveness and choice of the given investment. In addition, among 11 indications for different factors from those which were given to respondents, there were:

- project strengths, infrastructure, air quality, access to recreation areas, transportation,

- security,

- investor service,

- north- and south-facing flats,

- investment project,

- proximity of transportation and tram lines, availability of parking spaces, room layouts,

- surroundings, window view, urban-social infrastructure, e.g. public transportation,

- distinctive architecture,

- general location,

- functionality, and

- adaptation to the investor's payment options.

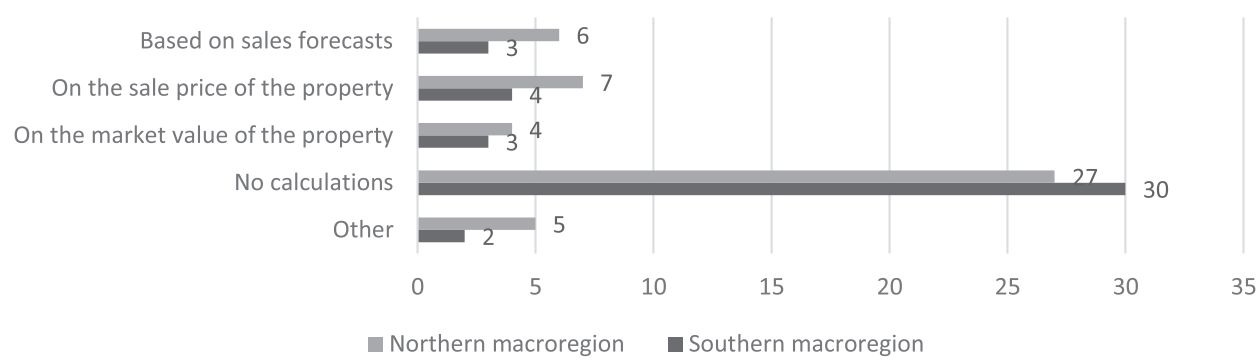

Figure 2. Factors determining the level of the rate of return on a given holiday rental investment

Source: Author's own study.

Based on the preliminary research and analysis of the rate of return offered by development companies, it was also decided to expand on this aspect and the representatives of development companies were asked a question about factors determining the annual rate of return, which is a profit for individual investors purchasing the given property (Figure 2). The offer aimed at investors provides information about the possibility of profit at $6 \%$ to $8 \%$ per annum. ${ }^{7}$ The answers given by respondents indicated that the

7 The profit offered at $6 \%$ to $8 \%$ annually is presented depending on the offer and the construction of the sales contract by a given development company. The possible options include: a) $6 \%$ to $8 \%$ of the profit generated from a given holiday property by the management firm, with the profit being independent 
profit value proposed to future owners was a hypothetical one because the basic variable determining the owner's profit was not recorded (the number of tourists staying in a given facility). In the "Other" option, there were also such answers as "We do not do such calculations because we only sell premises". This is an understandable and absolutely right attitude from the viewpoint of development companies, which, in consequence of their activities, sell holiday properties to individual investors, who continue to manage their property on their own. However, preliminary research indicates that the investment in real estate generates profit at $6 \%$ to $8 \%$ per annum. It is concluded that this activity is not reflected in reality in any way and is assumed to be a marketing activity. The profit at $6 \%$ to $8 \%$ generated from the money invested in the holiday property is financed for the first two years and guaranteed in real estate purchase contracts signed when the property is bought from the developer. Holiday property is not well-known on the tourist market within the first two to three years; therefore, it is rented to a small extent by tourists. Thus, the following question needs to be answered: what will happen if the development company misjudges the factors affecting the investor's choice and future individual investors are not interested in the real estate?

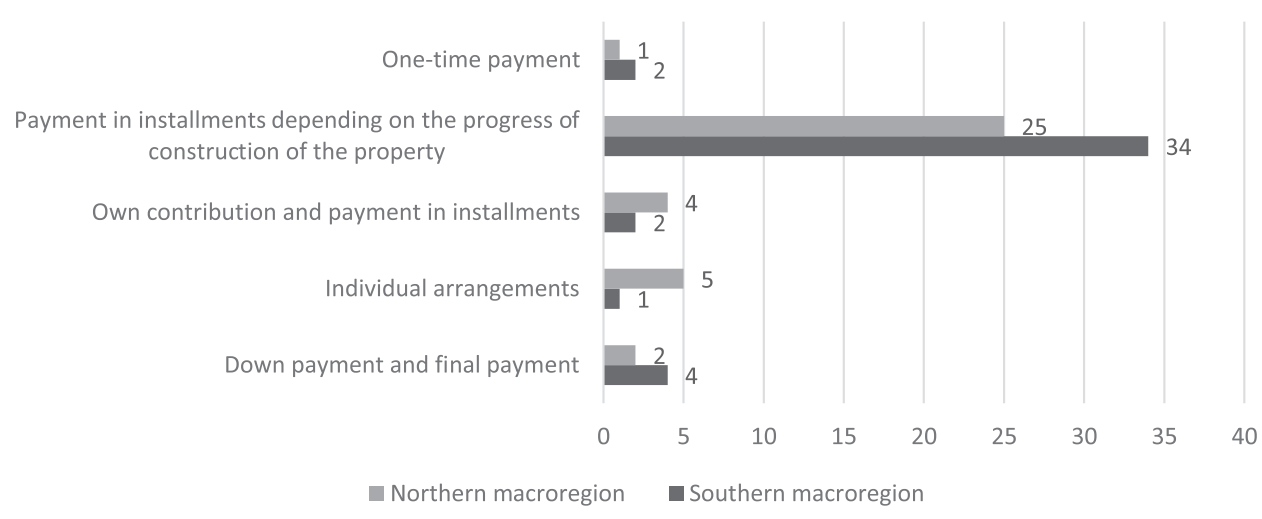

Figure 3. Payment schedule for a holiday investment for sale

Source: Author's own study.

This type of investment is mostly financed with a loan (over $70 \%$ of indications for this source of financing for a summer investment for sale). However, it seems that this type of financing for carrying out the construction work of holiday properties for sale is a relatively safe means of investment implementation from the viewpoint of development companies, because the payment schedule depends on the degree of investment implementation (Figure 3, 59 indications in the survey in each of the analysed

of the level of costs - the costs are fixed and paid as a lump sum; b) $6 \%$ to $8 \%$ of the fixed value regardless of the number of days booked by tourists, with the fixed value being paid as a lump sum to the owner; c) $6 \%$ to $8 \%$ of the generated profit calculated on the grounds of the number of days booked for a given holiday property after deducting all costs related to service and administration. 
areas). In view of the findings above, it seems justified that liquidity risk (Figure 4, 4 indications as to the risk related to development activity) in the case of development companies and potential threats to the real estate market and development industry, are not as significant since developers will be trying to shift at least part of their own credit burden to investors buying rental property by means of raising property selling prices.

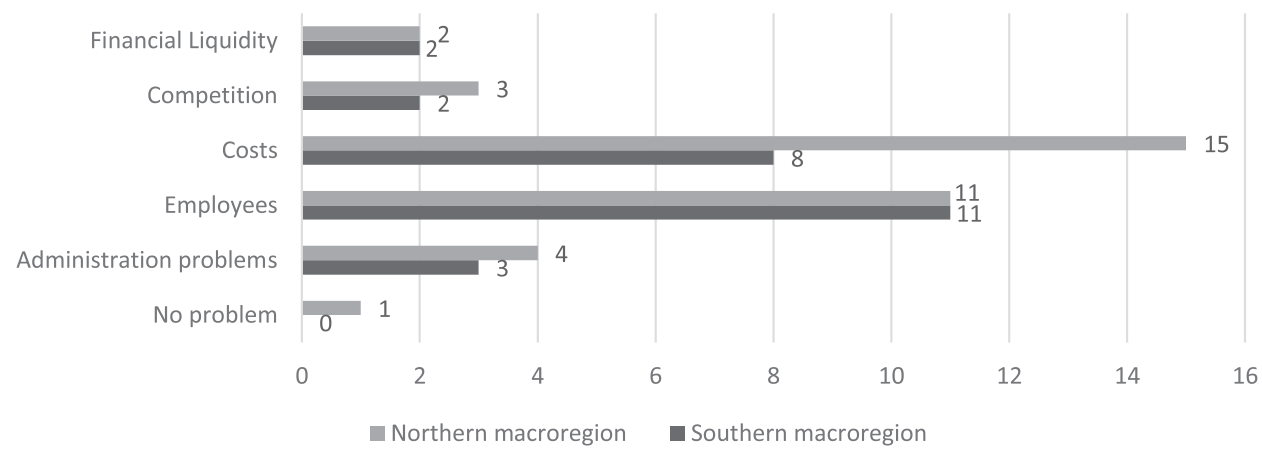

Figure 4. Problems with conducting development business in Poland

Source: Author's own study.

Problems related to this kind of investment made by development companies seem to be minimised by the level of demand by which such investments are characterised (Figure 5). In the survey, a question was asked about the level of sold investments which were still under construction. The most often indicated answer option was the sale of $50 \%$ of the ongoing investment. Therefore, it could be assumed that the remaining holiday properties at their preparation stage still did not have investors. This number also depended on the number of ongoing investments. The most commonly used practice was the sale of the real estate whose construction had not been started yet or which was already under construction. The least common solution was the sale of finished buildings (less than $3 \%$ of indications).

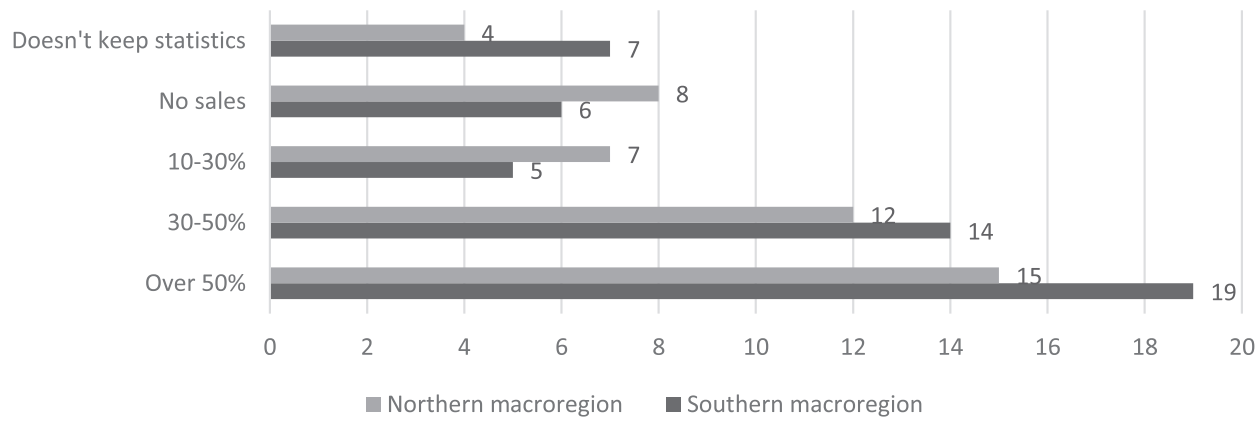

Figure 5. Percentage of sold real estate in relation to properties offered by development companies Source: Author's own study. 
Qualitative research did not show any differences between regions in the area of the surveyed characteristics; thus, the third stage of the study was carried out to verify the conclusions drawn from the conducted surveys.

\section{Statistical surveys regarding the market of holiday properties and residential premises}

To supplement the qualitative research, the statistical tests were conducted. The aim was to find statistically significant differences in the answers given by the respondents from the northern and southern macroregions.

Table 1. Mann-Whitney test for survey questions

\begin{tabular}{|c|l|l|l|l|l|l|l|l|}
\hline Variable & $\begin{array}{c}\text { Sum of } \\
\text { ranks gr. 1 }\end{array}$ & $\begin{array}{c}\text { Sum of } \\
\text { ranks gr. 2 }\end{array}$ & \multicolumn{1}{c|}{$\mathrm{U}$} & $\mathrm{Z}$ & $\mathrm{p}$ & $\mathrm{Z}$ corr & $\mathrm{p}$ & Exact $\mathrm{p}$ \\
\hline Question 1 & 40.50000 & 37.50000 & 16.50000 & 0.160128 & 0.872780 & 0.160409 & 0.872559 & 0.818182 \\
\hline Question 2 & 34.50000 & 20.50000 & 5.500000 & 1.357806 & 0.174526 & 1.366110 & 0.171905 & 0.150794 \\
\hline Question 3 & 29.00000 & 26.00000 & 11.00000 & 0.208893 & 0.834532 & 0.212798 & 0.831485 & 0.841270 \\
\hline Question 4 & 53.50000 & 51.50000 & 15.50000 & 1.032796 & 0.301700 & 1.040833 & 0.297954 & 0.282384 \\
\hline Question 5 & 27.50000 & 27.50000 & 12.50000 & 0.00 & 1.000000 & 0.00 & 1.000000 & 1.000000 \\
\hline
\end{tabular}

Source: Author's own study.

On the basis of the presented data, it should be acknowledged that the assumed significance level of 0.05 and the obtained results (values) for all analysed dependencies in questions 1-5 indicate that there are no statistically significant differences in the results obtained in the northern and southern macroregions. This means that the factors determining the investors' choices of the given holiday property are similar for both macroregions - individual investors buying real estate by the sea and those buying in the mountains follow the same selection criteria (question 1). Factors determining the rate of return on the given rental investment are also similar, but the statistical interpretation of the results does not seem to be entirely correct because most respondents stated that they did not do calculations related to rates of return (question 2). In the case of the payment schedule, it is not possible to determine statistically significant differences; thus, it is assumed that the payments for properties purchased at the seaside and for those in the mountains are made in a similar manner (question 3). The analysis of the occurrence of statistically significant differences concerning problems related to the preparation of the holiday property for sale by developers showed that, according to the answers given, the differences were similar for the two analysed macroregions (question 4). The percentage of real estate sold in relation to properties offered by development companies showed that the sum of ranks in group 1 (northern macroregion) and in group 2 (southern macroregion) was 
similar; therefore, it can be assumed that the demand for offered holiday properties is very similar. Additionally, based on the analysis of the distribution of responses, it is noteworthy that the demand for this type of property is high on a national scale. Therefore, during the second stage of the empirical study, it was decided to build the trial model in which the explained variable is the number of completed dwellings. Holiday properties are part of the housing market. In addition, it can be acknowledged that they meet similar needs. ${ }^{8}$ It can also be noted that very often, both residential premises and holiday properties are commissioned by the same development companies. Based on this, it can be assumed that the development of the residential market will also be similar for the development of the holiday real estate market, with a similar growth rate for both markets. In addition, there is an absence of legal regulations (for the purpose of capital allowances, holiday rentals are referred to as residential premises). The choice of three variables for the model results from the following assumptions:

1. As the average remuneration increases, the willingness to invest and buy residential premises also increases - during the first stage to satisfy the housing needs, during the second stage to diversify the portfolio of investments (the transition from the first stage to the second stage comes with ageing).

2. The number of completed residential premises reflects the supply and the developer's capacity in the construction industry.

3. The number of marriages is the result of the assumption that the marriage aims to create an independent and separate household, and buying a flat is a strategy to achieve the established goal. In accordance with the adopted methodology for model building, first, the statistical measures for explanatory variables and the explained variable needed to be calculated.

Table 2. Statistical measures for explanatory variables and the explained variable

\begin{tabular}{|l|c|c|c|}
\hline \multicolumn{1}{|c|}{ Measures } & Monthly remuneration & Number of marriages & $\begin{array}{c}\text { Number of completed } \\
\text { residential premises }\end{array}$ \\
\hline Mean & $2,590.8$ & $208,809.5$ & $60,501.3$ \\
\hline Standard deviation & 1049.204292 & 20983.39251 & 19508.14052 \\
\hline Coefficient of variation $(\mathrm{CV})$ & 0.404980774 & 0.100490592 & 0.322441652 \\
\hline
\end{tabular}

Source: Author's own study.

During the second stage of building the model, the correlation coefficients between variables needed to be checked. Based on the coefficient of variation, no variable should be rejected in the model-building process.

8 Needs - as the financial situation of Poles improves, the willingness to invest and diversify their portfolio of assets increases, e.g. by purchasing residential premises or holiday properties. 
Pobrane z czasopisma Annales H - Oeconomia http://oeconomia.annales.umcs.pl

Data: 26/04/2023 10:49:32

JUSTYNA BOGOŁĘBSKA

Table 3. Correlation for explanatory variables and the explained variable

\begin{tabular}{|l|c|c|c|}
\hline \multicolumn{1}{|c|}{ Correlation } & $\mathrm{x} 1$ & $\mathrm{x} 2$ & $\mathrm{y}$ \\
\hline Remuneration $-\mathrm{x} 1$ & 1 & -0.105984015 & 0.743122083 \\
\hline Number of marriages $-\mathrm{x} 2$ & & 1 & -0.014648562 \\
\hline Number of completed residential premises $-\mathrm{y}$ & & & 1 \\
\hline
\end{tabular}

Source: Author's own study.

The selection of variables for the model by means of the correlation coefficient indicates a negative correlation between variable $\mathrm{x} 1$ and variable $\mathrm{x} 2$. During the last stage of the study, the structural parameters for $\mathrm{x} 1$ and $\mathrm{x} 2$ were estimated by means of the least squares method.

Table 4. Assessment of structural parameters for variable $\mathrm{x} 1$ and $\mathrm{x} 2$ by means of the least squares method

\begin{tabular}{|l|c|c|c|c|}
\hline & Coefficients & Standard error & $t$ Stat & $p$ value \\
\hline $\mathrm{X}$ & 11786.59945 & 30821.89893 & 0.382409905 & 0.706190852 \\
\hline Remuneration & 13.9448415 & 2.784811141 & 5.007463988 & $6.75613 \mathrm{E}-05$ \\
\hline Marriages & 0.060280271 & 0.139245158 & 0.432907488 & 0.669714554 \\
\hline \multicolumn{2}{|c|}{} & \multicolumn{2}{|c|}{ Collinearity statistics } & \multirow{2}{*}{$\begin{array}{c}\text { Durbin-Watson } \\
\text { statistics }\end{array}$} \\
\cline { 3 - 4 } & Margin of error & VIF & \multirow{2}{*}{1.834} \\
\hline
\end{tabular}

Source: Author's own study.

Therefore, the model assumes the form $y=13.96 \times 1+0.06 \times 2+11786$. This means that as variable $\mathrm{x} 1$ (average remuneration) increases by one unit, the number of completed residential premises increases by 13.96 units, with the value of parameter $\mathrm{x} 2$ remaining unchanged. However, as parameter $\mathrm{x} 2$ (number of marriages) increases, the number of completed residential premises increases by 0.06 , with the value of parameter $\mathrm{x} 1$ remaining unchanged. The calculated VIF coefficient provides information about the collinearity between the explanatory variables, which was limited in the indicated collation. The Durbin-Watson test showed the lack of autocorrelation between the variables. The last step was to check the regression statistics.

Table 5. Regression statistics

\begin{tabular}{|l|c|}
\hline \multicolumn{2}{|c|}{ Regression statistics } \\
\hline Multiplication of $\mathrm{R}$ & 0.74591372 \\
\hline $\mathrm{R}^{2}$ & 0.556387278 \\
\hline Adjusted $\mathrm{R}^{2}$ & 0.512026006 \\
\hline Standard error & 13627.43797 \\
\hline $\mathrm{O}$ & 23 \\
\hline
\end{tabular}

Source: Author's own study. 
The value of $\mathrm{R}^{2}$ at 0.55 shows the influence of the group of predictors ( $\mathrm{x} 1$ and $\mathrm{x} 2$ in the adopted model, average remuneration and number of marriages) - the factors which affect the explained variable (number of completed residential premises). The model also has some limitations due to its assumptions: 1) not every married couple is interested in buying an apartment, 2) the number of completed dwellings does not reflect the residential premises actually purchased by married couples. This is the trial model which was intended for predicting the number of completed apartments in the future. In a limited way, this model provides more information about the possible forecast regarding the development of the holiday property market in the future.

\section{Conclusions}

The rising prices of construction and assembly works and staff shortages had a negative impact on the developers' situation, particularly in view of the persistently high number of sold apartments (see surveys). Gross housing investment increased in 2017 and amounted to approximately $1.5 \%$ in relation to GDP. The development investment accounted for approximately $50 \%$ of this value. Therefore, it is estimated that it is an attractive and forward-looking investment in the context of the given macroeconomic data (NBP, 2018), the increase in gross pay in Poland, the collected statistical data and the business profile of development companies within the scope of sold holiday properties. According to the data prepared by the Ministry of Finance, the number of payers declaring rental income in annual tax returns is also growing. Based on my own research, it can also be acknowledged that development companies will be preparing further investments in the area of selling holiday properties. This is because, from the viewpoint of the individual investor, this type of investment is particularly profitable since salaries in Poland are growing; thus, more people will be interested in investing and securing their future. Additionally, there is a possibility of taking advantage of the opportunities within the tax system, whose structure is conducive to tax optimisation as a result of purchasing holiday properties for rent. From the viewpoint of the Accounting Act, there are also benefits from the amortisation of newly purchased holiday properties for sale, which are recognised by law as residential premises and are amortised in the same manner.

\section{References}

Belniak, S. (2001). Rozwój rynku nieruchomości w Polsce na tle krajów wysoko rozwiniętych. Zeszyty Naukowe Akademii Ekonomicznej w Krakowie, (148).

Dziworska, K., \& Trojanowski, D. (2007). Kierunki rozwoju rynku nieruchomości w Polsce. In: K. Dziworska, T.G. Guerts, \& P. Lorens (red.), Strategie inwestowania w nieruchomości. Warszawa: Urbanista.

Hoesli, M., Lizieri, C.M., \& MacGregor, B.D. (1997). The spatial dimensions of the investment performance UK commercial property. Urban Studies, 34(9). doi:10.1080/0042098975529 
Pobrane z czasopisma Annales H - Oeconomia http://oeconomia.annales.umcs.pl Data: 26/04/2023 10:49:32

JUSTYNA BOGOŁĘBSKA

Kucharska-Stasiak, E. (2016). Ekonomiczny wymiar nieruchomości. Warszawa: PWN.

NBP. (2018). Raport o sytuacji na rynku nieruchomości mieszkaniowych i komercyjnych $w$ Polsce w $2017 \mathrm{r}$.

Retrieved from https://www.nbp.pl/publikacje/rynek_nieruchomosci/raport_2017.pdf

SW RESEARCH. (2016, 17 August). Preferencje turystyczne Polaków 2016 - raport dla Travel-

Planet. Retrieved from https://swresearch.pl/raporty/czytaj/id/59/preferencje-turystyczne-po-

lak-w-2016-raport-dla-travelplanet

Witkowska, D. (2012). Podstawy ekonometrii i teorii prognozowania. Warszawa: Wolters Kluwer. 